GRASAS Y ACEITES, 63 (4), OCTUBRE-DICIEMBRE, 365-372, 2012, ISSN: 0017-3495

DOI: $10.3989 /$ gya.022212

\title{
Characterization of seed oils from different varieties of watermelon [Citrullus lanatus (Thunb.)] from Pakistan
}

\author{
By S. Raziq ${ }^{1}$, F. Anwar ${ }^{1,2, *}$, Z. Mahmood ${ }^{1}$, S. A. Shahid ${ }^{3}$ and R. Nadeem ${ }^{1}$ \\ ${ }^{1}$ Department of Chemistry and Biochemistry, University of Agriculture, Faisalabad-38040, Pakistan \\ ${ }^{2}$ Department of Chemistry, University of Sargodha, Sargodha-40100, Pakistan \\ ${ }^{3}$ Department of Physics, University of Agriculture Faisalabad-38040, Pakistan \\ *Corresponding author: fqanwar@yahoo.com
}

\begin{abstract}
RESUMEN
Caracterización de aceites de semillas de diferentes variedades de sandía [Citrullus lanatus (Thunb.)] procedentes del Pakistán.

Se presentan las características físico-químicas de aceites de diferentes variedades de semillas de sandías (Citrullus lanatus) cultivadas en Pakistán: Sugar Baby, QF-12, DWH-21 y Círculo rojo-1885. El aceite y el contenido de proteína cruda de las semillas de sandía están dentro de los rangos: $28,25-35,65 \%$ y $20,50-35,00 \%$, respectivamente y varian significativamente $(p<0,05)$ entre las variedades ensayadas. Los niveles de humedad, fibra cruda y cenizas en las semillas se encontró entre $2.16-3.24 \%, 1.95-3.42 \%$ y 4.29-6.60\%, respectivamente. Las características fisico-químicas estudiadas de los aceites extraídos fueron: contenido de ácidos grasos libres (1.17-2.10\% de ácido oleico), índice de yodo (97,10-116,32 $\mathrm{g} \mathrm{de}_{2} 100 \mathrm{~g}^{-1}$ de aceite), índice de saponificación (190,20-205,57 $\mathrm{mg}^{-1 e} \mathrm{KOH} \mathrm{g}{ }^{-1}$ de aceite), insaponificable $(0,54-0.82 \%)$ y color $(1.12-4.30$ de I +12.20 $33.40 \mathrm{y}$ ). Los aceites presentaron unos rangos de los parámetros de oxidación razonables, como se muestra en las determinaciones de la extinción específica a 232 y $270 \mathrm{~nm}$ (2.90-4.40 y 2.05-3.09 respectivamente), valores de $p$-anisidina (5.60-7.70) e índice de peróxidos (2,90-5,06 meqO kg $^{-1}$ de aceite). El ácido linoleico es el principal ácido graso que se encuentra en todos los aceites de las semillas, con una contribución del $45.30-51.80 \%$ del total de ácidos grasos. Otros ácidos grasos determinados fueron oleico, 20,2-23,5\%, palmítico, 15,1-16,9\%) y esteárico, 11,5-14,4\%. El contenido de $\alpha$ - y $\delta$-tocoferol en los aceites fué de 120,6-195,6 y 9,1$58,3 \mathrm{mg} \mathrm{kg}^{-1}$, respectivamente. Los atributos físico-químicos de los aceites de semillas de sandía variaron significativamente entre las variedades ensayadas. Los resultados del presente estudio indican que las semillas de las variedades de sandía ensayadas procedentes de Pakistán son una fuente potencial aceites con alto contenido en ácido linoleico $y$, por lo tanto, se puede explorar para usos comerciales y productos con valor añadido.
\end{abstract}

PALABRAS CLAVE: Aceite de semillas - Ácidos grasos Atributos físico-químicos - Estado de oxidación - HPLC Sandía - Tocoferoles.

\section{SUMMARY}

Characterization of seed oils from different varieties of watermelon [Citrullus lanatus (Thunb.)] from Pakistan.

This paper reports the physicochemical characteristics of the seed oils from different varieties of watermelon (Citrullus lanatus) cultivated in Pakistan, namely Sugar Baby, Q-F-12, D-W-H-21 and Red Circle-1885. The oil and crude protein contents from watermelon seeds, within the range of 28.25 to $35.65 \%$ and 20.50 to $35.00 \%$, respectively, varied significantly $(p<0.05)$ among the varieties tested. The levels of moisture, ash, and crude fiber in the seeds tested were found to be $2.16-3.24 \%, 1.95-3.42 \%$ and $4.29-6.60 \%$, respectively. The physicohemical characteristics of the extracted oils were: free fatty acid contents $(1.17-2.10 \%$ as oleic acid), iodine value (97.10-116.32 $\mathrm{g} \mathrm{of}^{2} 100 \mathrm{~g}^{-1}$ of oil), saponification index $\left(190.20-205.57 \mathrm{mg} \mathrm{KOH} \mathrm{g}^{-1}\right.$ of oil), unsaponifiable matter (0.54-0.82\%) and color (1.12-4.30 R + 12.20-33.40 Y). The oils revealed a reasonable oxidative parameter range as depicted by the determinations of specific extinction at 232 and $270 \mathrm{~nm}$ (2.90-4.40 and 2.053.09 , respectively), $p$-anisidine value $(5.60-7.70)$ and peroxide value (2.90-5.06 meqO $\mathrm{kg}^{-1}$ of oil). Linoleic acid was the major fatty acid found in all the seed oils with contributions of $45.30-51.80 \%$ of the total fatty acids (FA). Other fatty acids detected were known to be oleic acid (20.2$23.5 \%)$, palmitic acid (15.1-16.9\%) and stearic acid (11.5$14.4 \%)$. The contents of $\alpha$ - and $\delta$-tocopherol in the oils accounted for $120.6-195.6$ and $9.1-58.3 \mathrm{mg} \mathrm{kg}^{-1}$, respectively. The physicochemical attributes of the watermelon seed oils showed a wider variation among the varieties tested. The results of the present study indicate that the seeds of the tested watermelon varieties from Pakistan are a potential source of high-linoleic oil and thus can be explored for commercial use and value addition.

KEY-WORDS: Fatty acids - HPLC - Oil seeds Oxidation state - Physicochemical attributes - Tocopherols - Watermelon.

\section{INTRODUCTION}

Several Cucurbitaceae species have been studied as potential sources of nutrients such as protein, minerals and lipids as well as ingredients for native medicine. Especially, the seed kernels from cucurbit fruits and vegetables such as melon, watermelon, cucumber and gourd, traditionally called "Charmagaz" are well-known in the subcontinental region for their therapeutic properties (Achu et al., 2005; Mabaleha et al., 2007).

Watermelon [(Citrullus lanatus (Thunb.)], belonging to the Cucurbitaceae family, is widespread in tropical and subtropical regions of the world (Achu et al., 2005). Watermelon is 
primarily consumed as a fruit because of its sweet flavor and high nutritional value. It has been widely used in several regions of the world, especially in Africa and Asia, not only as a source of nutrition but also as a folk remedy for the treatment of strangury (Artwatermelon, 2007; Ziyada and Elhussien, 2008).

Watermelon seeds have high nutritional value and are utilized for human consumption as snacks after salting and roasting in Arabian and Asian regions. The seeds are a rich source of protein 25.2$37 \%$ and oil $37.8-45.4 \%$ (Ziyada and Elhussien, 2008). El-Adawy and Taha (2001) investigated the chemical composition and characteristics of watermelon, pumpkin, and paprika seed oils and flours from Egypt. Watermelon seed oil is light in appearance, and is valued as a potential source of essential fatty acid (linoleic acid) with health benefits (Tiawo et al., 2008). Watermelon seed oils, often characterized by high-linoleic acid content, have been studied in different parts of the world such as West Africa and the Middle East (Taiwo et al., 2008; Ziyada and Elhussien 2008). Mabaleha et al. (2007) investigated the properties of selected melon seed oils to determine their potential uses for edible purposes.

All over the world, due to growing vegetable oil demand, much interest is currently being focused on the possibilities of exploring some newer and underutilized plant resources for the production of oils (Anhwange, 2004). For this reason, many fruit seed oils, as newer sources, have been evaluated for specific industrial or food uses (Parry et al., 2005; Mabaleha et al., 2007; Ramadan et al., 2006; Adhikari et al., 2008; Anwar et al., 2008; Celik and Ercisli, 2009; Matthaus and Ozcan 2009; Nehdi, 2011).

According to Pakistan Oilseeds and Products Annual Report (POPA, 2011) vegetable oils imported to Pakistan have been estimated to be 2.16 million metric tons (MMT) for the marketing year 2011-2012. Nearly 75 percent of the total domestic consumption (3.5 MMT) of vegetable oil in Pakistan is met through imports (POPA, 2011) while only 25 percent is derived from the local vegetable oilseed resources. Therefore, it is worthwhile to investigate some non-conventional oil seed resources of Pakistan, to bridge the gap between supply and demand. Although considerable work has been carried out on the nutritional analysis of seed and seed oils from several cucurbit fruits, no data are known on the detailed physicochemical characteristics of fruit seed oils from important cultivars of watermelon (Citrullus lanatus) grown in Pakistan. Watermelon fruit is widely consumed in Pakistan yielding a considerable amount of seeds, which are often discarded as waste. In line with the present needs, these seeds can be used for oil extraction. The present work was therefore designed with the main objective of evaluating the physicochemical characteristics including the fatty acid and tocopherol profiles of seed oils produced from different cultivars of locally grown watermelon.

\section{MATERIALS AND METHODS}

\subsection{Materials}

The seeds of four watermelon (Citrullus lanatus) varieties (Sugar Baby, Q-F-12, D-W-H-21 and Red Circle 1885) were obtained from the Ayub Agricultural Research Institute, Jhang Road, Faisalabad, Pakistan. Three different seed samples for each of the varieties were harvested. The chemicals and reagents (analytical and HPLC grade) used throughout the experiment were from Merck (Darmstadt, Germany) or Sigma Aldrich (Buchs, Switzerland). Pure standards of tocopherols [DL- $\alpha-$ tocopherol, (+)- $\gamma$-tocopherol, (+)- $\delta$-tocopherol], and fatty acid methyl esters (FAMEs) were purchased from Sigma Chemical Co. (St Louis, MO, USA).

\subsection{Extraction of oil}

Samples of watermelon seeds (dried at $40^{\circ} \mathrm{C}$ in an oven for $24 \mathrm{~h}$ ) were crushed using a commercial blender (TSK-949, Westpoint, France). One hundred grams of well-crushed seeds of each variety were placed in a paper thimble and fed into a Soxhlet extractor. The extractor was fitted with a $1 \mathrm{~L}$ round bottomed flask and a water condenser. The oil extraction was carried out with $n$-hexane on a water bath for $6 \mathrm{~h}$. The extra hexane, after oil extraction, was removed by distilling off under low pressure through a rotary evaporator (EYELA, N-N Series; Rikakikai Co Ltd., Tokyo, Japan).

\subsection{Analysis of oilseed cake}

The oilseed cake, obtained after the oil extraction from the seeds, was analyzed for protein, fiber, and ash contents. Protein content (percent $\mathrm{N} \times 6.25$ ) was estimated according to the Association of Official Analytical Chemists AOAC standard method 976.06 (AOAC, 1990) using a Kjeldahl apparatus. The fiber and ash contents were determined according to the ISO method 5983 (ISO, 1981) and ISO method 749 (ISO, 1977), respectively.

\subsection{Physical and chemical parameters of oils}

The extracted oils were analyzed for density, refractive index, iodine value (IV), peroxide value (PV), acidity, saponification index and unsaponifiable matter following AOCS official methods Cc 10a-25, Cc 7-25, Cd 1-25, Cd 8-53, F 9a-44, Cd 3-25, and Ca 61-40, respectively (AOCS, 1997). The oil color, in a 1-in. cell, was checked using a Lovibond Tintometer (Tintometer Ltd., Salisbury, Wiltshire, United Kingdom). Specific extinctions at 232 and $270 \mathrm{~nm}$, representing the magnitude of primary and secondary oxidation products of oils, were monitored using a spectrophotometer (U-2001; Hitachi, Instruments Inc., Tokyo, Japan). The oil samples were mixed with iso-octane to take the absorbance 
readings and $\left[\left(\varepsilon^{1 \%}{ }_{1 \mathrm{~cm}}(\lambda)\right]\right.$ were calculated according to the IUPAC method II D.23 (IUPAC, 1987). The $p$-anisidine value was determined according to IUPAC method II. D. 26 (IUPAC, 1987). The oil samples, dissolved in iso-octane, were allowed to react with para-anisidine for $10 \mathrm{~min}$. The absorbance of the colored complex formed was recorded at 350 $\mathrm{nm}$, using a spectrophotometer.

\subsection{Fatty acid composition}

The oil samples were transformed into fatty acid methyl esters (FAMEs) through transmethylation according to the IUPAC standard method 2.301 (IUPAC, 1987) and analyzed by a SHIMADZU gas chromatograph model 17-A, fitted with an FID. The separation of FAMEs was done on an SP-2330 (SUPELCO, INC., Supelco Park, Bellefonte, PA, 16823-0048 USA) methyl-lignocerate-coated (film thickness $0.20 \mu \mathrm{m})$, polar capillary column $(30 \mathrm{~m} \times$ $0.32 \mathrm{~mm}$ ). Extra pure nitrogen gas at a flow rate of $3.5 \mathrm{~mL} \mathrm{~min}^{-1}$ was used as the mobile phase. The column oven temperature started at $180^{\circ} \mathrm{C}$ and was raised to $220^{\circ} \mathrm{C}$ at the linear ramp rate of $5^{\circ} \mathrm{C}$ $\mathrm{min}^{-1}$. The initial and final column temperature was held for 2 and 10 minutes, respectively. The injector and detector were adjusted to $230^{\circ} \mathrm{C}$ and $250^{\circ} \mathrm{C}$, respectively. The identification of the unknown FAMEs was based on matching their retention times with those of pure standards and quantified on the basis of peak areas by a Chromatography Station for Windows (CSW32) data-handling program (Data APEX Ltd., Pague 5, The Czech Republic). The FA composition was expressed as a relative percentage of the total peak area.

\subsection{Tocopherol content}

Tocopherols ( $\alpha$ and $\delta$ ) were analyzed by HPLC according to the Current Protocols in Food Analytical Chemistry methods (Wrolstad, 2003). The oil $(0.1 \mathrm{~g})$, mixed with $0.05 \mathrm{~g}$ ascorbic acid to protect from oxidation, was placed in an appropriate test tube. Five $\mathrm{mL}$ of $90 \%$ ethanol and $0.5 \mathrm{~mL}$ of $80 \%$ aqueous $\mathrm{KOH}$ solution were added to the test tube and the reaction mixture was mixed well by vortexing for $30 \mathrm{~s}$. The test tube was flushed with nitrogen to provide an inert environment, capped and then incubated in a water bath $\left(70^{\circ} \mathrm{C}\right)$ for 30 min with periodic vortexing. After that, the tube was removed and placed in an ice bath for $5 \mathrm{~min}$, then 3 $\mathrm{mL}$ deionized water and $5 \mathrm{~mL} n$-hexane were added and the mixture was vortexed for $30 \mathrm{~s}$. The tube was subjected to centrifugation at $1,000 \times g$ for $10 \mathrm{~min}$, at room temperature and the upper hexane layer was recovered in another test tube. The aqueous layer and the residue were reextracted using the same procedure. The upper hexane layers from both the extractions were combined and evaporated to dryness under nitrogen. The extract recovered was dissolved in one $\mathrm{mL}$ mobile phase, mixed well and then transferred to an HPLC sample vial. A $20-\mu \mathrm{L}$ sample was injected into a Supelcosil LCSi column $(250 \times 4.6 \mathrm{~mm}$, Supelco Inc.). Elution was made using a mobile phase of ethyl acetate/acetic acid/ hexane $(1: 1: 198, \mathrm{v} / \mathrm{v} / \mathrm{v})$ at the flow rate of $1.5 \mathrm{~mL} \mathrm{~min}^{-1}$. Detection was performed at $295 \mathrm{~nm}$. Tocopherols were identified by matching their retention times with those of pure standards of $\alpha$ and $\delta$-tocopherols and were quantified on the basis of peak areas based on an external standard method. A D-2500 Hitachi Chromatointegrator model with a built-in computer program for data handling was used for quantification.

\subsection{Statistical Analysis}

All the measurements were made in triplicate and the results statistically compared and analyzed by using one way analysis of variance (ANOVA). The values are reported as means with standard deviations for three replicates (Steel et al., 1997). A probability value at $p \leq 0.05$ was considered to denote statistically significant differences.

\section{RESULTS AND DISCUSSION}

\subsection{Proximate composition of seeds}

The results for the proximate composition of four different varieties of Pakistani watermelon seeds are depicted in Table 1. Hexane-extracted oil contents from watermelon seeds varied from

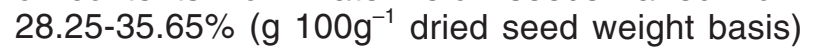
among the varieties tested. The highest (35.65\%) oil yield was exhibited by watermelon var. Q-F-12, whereas the lowest $(28.25 \%)$ by var. Red circle-1885 showing significant variation $(p<0.05)$ among the varieties tested which might be linked to the their differing genetic makeup. The watermelon seed oil contents as determined in the present work was comparable to that reported (35.50\%) for watermelon (Citrullus lanatus) seeds var. Colocynthoide investigated from Sudan (Ziyada and Elhussien, 2008). However, the present oil yield was lower than that reported by Oyedeji and Oderinde (2006) for Nigerian watermelon seeds (oil contents $45 \%$ ). Another study conducted by Baboli and Kordi (2010) revealed the hexane-extracted oil content from watermelon seeds $(50 \%)$ to be significantly higher than the present data. Such variation in oil yield from different regions might be attributed to the varied agroclimatic conditions employed for the growing of such fruits. The levels of seed oil contents (28.25\%-35.65\%) were found to exceed those of three other conventional oilseed crops including cotton (15.0$24.0 \%$ ), soybean $(17.0-21.0 \%$ ) and olive (20.025.0\%) (Pritchard, 1991).

The amount of seed protein, determined as $20.50-35.00 \%$, varied significantly $(P<0.05)$ among the varieties tested. Watermelon var. $\mathrm{D}-\mathrm{W}-\mathrm{H}-21$ exhibited the highest protein contents 
Table 1

Proximate composition (g $100 \mathrm{~g}^{-1}$ dried seed weight basis) of different varieties of watermelon seeds

\begin{tabular}{lcccc}
\hline \multirow{2}{*}{ Parameters } & \multicolumn{4}{c}{ Varieties } \\
\cline { 2 - 5 } & Sugar Baby & Q-F-12 & D-W-H-21 & Red Circle-1885 \\
\hline Oil & $30.08 \pm 1.90^{\mathrm{ab}}$ & $35.65 \pm 2.30^{\mathrm{bc}}$ & $32.22 \pm 2.09^{\mathrm{b}}$ & $28.25 \pm 1.50^{\mathrm{a}}$ \\
Ash & $3.00 \pm 0.12^{\mathrm{cd}}$ & $2.00 \pm 0.10^{\mathrm{ab}}$ & $1.95 \pm 0.90^{\mathrm{ab}}$ & $3.42 \pm 0.15^{\mathrm{cd}}$ \\
Protein & $20.5 \pm 1.09^{\mathrm{a}}$ & $24.5 \pm 1.50^{\mathrm{b}}$ & $35.00 \pm 2.50^{\mathrm{d}}$ & $29.00 \pm 1.42^{\mathrm{c}}$ \\
Moisture & $2.16 \pm 0.04^{\mathrm{a}}$ & $3.14 \pm 0.05^{\mathrm{cd}}$ & $3.24 \pm 0.08^{\mathrm{c}}$ & $3.00 \pm 0.04^{\mathrm{bc}}$ \\
Fiber & $5.29 \pm 0.50^{\mathrm{b}}$ & $6.60 \pm 0.11^{\mathrm{c}}$ & $4.29 \pm 0.08^{\mathrm{a}}$ & $5.23 \pm 0.09^{\mathrm{b}}$ \\
\hline
\end{tabular}

Different superscript letters within the same row indicate significant differences $(p<0.05)$ among varieties tested

Values are mean \pm SD of triplicate determinations

$(35.00 \%)$ whereas the var. Sugar Baby had the lowest $(20.50 \%)$. The protein contents of Pakistani watermelon seeds were in line with those reported $(26.33 \%)$ for watermelon seeds from Nigeria (Taiwo et al. 2008). The ash and fiber contents of the tested watermelon seeds ranged from 1.95-3.42\% and 4.29-6.60\%, respectively; although they did not compare with watermelon seeds from other regions. However, they were in line with a previous investigation (3.95\% and $3.44 \%$, respectively) of another melon type, the Cucurbita maxima seed (Achu et al., 2005).

\subsection{Physiochemical characteristics of oils.}

The results of various physicochemical characteristics of the extracted oils from the different varieties of watermelon seeds are given in Table 2 .

Among the varieties tested, the seeds oils investigated exhibited no significant $(P>0.05)$ variation with regard to the values of refractive index $\left(40^{\circ} \mathrm{C}\right)$ and density $\left(24^{\circ} \mathrm{C}\right)$, which ranged from 1.4665-1.4670 and 0.902-0.935 $\mathrm{mg} \mathrm{mL}^{-1}$, respectively. The present results were quite comparable to those reported for refractive index
(1.465-1.469) and density (0.874-0.954 mg/mL), in five different varieties of melon seeds including one var. of Citrullus lanatus from Ghana (Mabaleha et al., 2007). Among the varieties tested, Red circle-1885 showed the lowest value for density (0.902) and the highest for refractive index (1.4670). While Sugar Baby had the highest density (0.935), it also revealed the lowest refractive index (1.4665). Pure oils have characteristic refractive index and density ranges thus the degree of variation of such data from the true value may indicate its relative purity.

The color values for the investigated watermelon seed oils (12.2-33.4Y/ 2.1-4.3R), although varying significantly $(P<0.05)$ within the varieties tested, were quite low, indicating that these oils could be employed for edible or other oleochemical uses after slight bleaching. The development of color in vegetable oils is mainly linked with the presence of some coloring matters/pigments, for example, chlorophyll and carotenoids which are extracted along with the oil during the process of oilseed extraction. Such coloring components have to be thoroughly removed through a step known as oil bleaching. Lighter colored oils, being valuable from

Table 2

Physicochemical characteristics of different varieties of watermelon seed oils

\begin{tabular}{lrrrr}
\hline \multirow{2}{*}{ Parameters } & \multicolumn{3}{c}{ Varieties } \\
\cline { 2 - 5 } & Sugar Baby & Q-F-12 & \multicolumn{1}{c}{ D-W-H-21 } & Red Circle-1885 \\
\hline Free fatty acid $(\%$ as oleic acid) & $1.30 \pm 0.30^{\mathrm{ab}}$ & $1.17 \pm 0.35^{\mathrm{a}}$ & $1.90 \pm 0.45^{\mathrm{bc}}$ & $2.10 \pm 0.50^{\mathrm{c}}$ \\
lodine value $\left(\mathrm{g}\right.$ of $\mathrm{I}_{2} 100 \mathrm{~g}^{-1}$ of oil) & $97.10 \pm 2.14^{\mathrm{a}}$ & $103.25 \pm 2.50^{\mathrm{b}}$ & $116.32 \pm 2.90^{\mathrm{cd}}$ & $114.00 \pm 2.62^{\mathrm{c}}$ \\
Density $\left(24^{\circ} \mathrm{C}, \mathrm{mg} \mathrm{mL}^{-1}\right)$ & $0.93 \pm 0.12^{\mathrm{b}}$ & $0.91 \pm 0.10^{\mathrm{a}}$ & $0.91 \pm 0.20^{\mathrm{a}}$ & $0.90 \pm 0.15^{\mathrm{a}}$ \\
Refractive index $\left(40^{\circ} \mathrm{C}\right)$ & $1.4665 \pm 0.002^{\mathrm{ab}}$ & $1.4668 \pm 0.005^{\mathrm{cd}}$ & $1.4667 \pm 0.001^{\mathrm{bc}}$ & $1.4670 \pm 0.003^{\mathrm{cd}}$ \\
Saponification index $\left(\mathrm{mg}\right.$ of $\mathrm{KOH} \mathrm{g}^{-1}$ oil) & $199.81 \pm 3.15^{\mathrm{c}}$ & $205.57 \pm 3.20^{\mathrm{d}}$ & $196.84 \pm 3.12^{\mathrm{bc}}$ & $190.20 \pm 3.00^{\mathrm{a}}$ \\
Unsaponifiable mater $(\%)$ & $0.82 \pm 0.10^{\mathrm{c}}$ & $0.54 \pm 0.16^{\mathrm{a}}$ & $0.56 \pm 0.15^{\mathrm{ab}}$ & $0.63 \pm 0.12^{\mathrm{b}}$ \\
Color (yellow unit) & $33.40 \pm 1.60^{\mathrm{d}}$ & $33.30 \pm 1.42^{\mathrm{d}}$ & $12.20 \pm 1.60^{\mathrm{a}}$ & $16.85 \pm 1.90^{\mathrm{b}}$ \\
Color (red unit) & $2.10 \pm 0.21^{\mathrm{b}}$ & $4.30 \pm 0.15^{\mathrm{d}}$ & $2.10 \pm 0.08^{\mathrm{b}}$ & $1.12 \pm 0.12^{\mathrm{a}}$ \\
\hline
\end{tabular}

Different superscript letters within the same row indicate significant differences $(p<0.05)$ among varieties tested

Values are mean \pm SD of triplicate determinations 
a technical view-point, are thus more acceptable for edible or oleochemical applications.

The contents of free fatty acids (FFA), calculated as percent oleic acid, for the different varieties of watermelon seed oils were found to be $1.17-2.10 \%$, with the highest value in watermelon var. Red circle-1885 while the lowest was found in var. Q-F-12. FFAs are the measure of extent to which hydrolysis has hydrolyzed and liberated the oil fatty acids from their parent molecule ester linkages. The contents of FFA as determined in the present analysis were found to be higher than those reported (1.20$4.00 \%$ ) earlier by Mabaleha et al., (2007) for five different varieties of melon seed oils from Ghana. Generally, a higher FFA value of the oil correlates with a higher magnitude of hydrolytic deterioration, thus poor oil quality due to the generation of objectionable flavors and bad odors.

The saponification index (SI) was determined to be 190.20-205.57 (mg of $\mathrm{KOH} \mathrm{g}{ }^{-1}$ of oil) for the tested oils and differed significantly $(P<0.05)$ among the varieties analyzed. These SI are in line with those reported ( $200.00 \mathrm{mg}$ of $\mathrm{KOH} \mathrm{g}^{-1}$ of oil) by Baboli and Kordi (2010) for watermelon seed oil, however higher than those (182.10-193.80 mg of $\mathrm{KOH} \mathrm{g}{ }^{-1}$ of oil) investigated for different melon seed oils from Ghana (Mabaleha et al., 2007). Such differences in SI might be attributed to the replacement of long chain $\left(\mathrm{C}_{22}\right)$ fatty acids by shorter chain $\mathrm{C}_{18}$ fatty acids of the oils analyzed (Anwar et al., 2006).

The amount unsaponifiable matter (USM) of the investigated varieties of watermelon oils ranged from $0.54-0.82 \%$. These values were lower than those reported $(0.68-4.18 \%)$ earlier for melon seeds oil by Anwer et al., (2006). Higher oil USM reflects the presence of higher concentration of valuable minor components such as tocopherols, carotenoids, squalene and phytosteroals which not only impart oxidative stability to the oils but also have potential medicinal value. Mostly the concentration of USM constitutes up to 0.50 to $2.50 \%$, however in exceptional cases 5 to $6 \%$ of vegetable oils (Bockisch, 1993; Gordon and Magos, 1983; Malecka, 1994).

The iodine value (IV) of the investigated oils, ranging from $97.10-116.32$ (g of $\mathrm{I}_{2} 100 \mathrm{~g}^{-1}$ of oil), varied significantly $(P<0.05)$ among the varieties analyzed. These results are in close agreement to those reported in for five varieties of melon oil (95.80-124.00 $\mathrm{g}_{\text {of }} \mathrm{I}_{2} 100 \mathrm{~g}^{-1}$ of oil) investigated by Mabaleha et al., (2007) from Ghana. It is well recognized that IV is the measurement of the degree of unsaturation of the fatty acids present in an oil, principally the oleic and linoleic acids. A high iodine value means that the oil is more unsaturated and could be used for edible purposes. This value is helpful in determining the quality of the oil, whether as a drying, semi-drying or non-drying oil. The iodine value is also related to the melting point or hardness of an oil or fat. The iodine value of an oil is reported to decrease as a result of unfavorable storage conditions, especially temperature, due to the oxidation of unsaturated fatty acids (Rossell, 1991).

\subsection{Oxidation parameters of seed oils}

The oils extracted from the tested varieties of watermelon seeds showed good oxidation states as indicated by the data for the different parameters presented in Table 3.

The specific extinction at $232 \mathrm{~nm}$ and $270 \mathrm{~nm}$, which revealed the magnitude of oxidative deterioration (Rossell, 1991; Frankel, 2005), of the watermelon seed oils ranged from 2.90-4.40 and 2.05-3.09, respectively, indicating a significant $(p<0.05)$ variation among the varieties tested. These values of specific extinctions at $232 \mathrm{~nm}$ and $270 \mathrm{~nm}$ which were found to be comparable with those investigated (4.80 and 3.52, respectively) in another cucurbit i.e. pumpkin (Cucurbita pepo) seed oil analyzed by Ardabili et al., (2011) from Iran, could not be specifically compared with watermelon seed oils due to the lack of investigations in the literature.

The peroxide value (PV) is a measurement of those substances in a sample expressed in terms of mili-equivalents of active oxygen per kilograms of oil sample which oxidize potassium iodide under the conditions of the test. PV is usually used to measure the oxidative rancidity of an oil or fat. The $\mathrm{PV}$ of watermelon seed oils ranged from 2.90 to $5.06 \mathrm{meqO}_{2} \mathrm{~kg}^{-1}$ with the lowest value for the variety Sugar Baby while the highest value was found for $\mathrm{Q}-\mathrm{F}-12$. The present $\mathrm{PV}$, noted to be considerably lower than that investigated in pumpkin seed oil

Table 3

Oxidation parameters of different varieties of watermelon seed oils

\begin{tabular}{lcccc}
\hline \multicolumn{1}{c}{ Parameters } & \multicolumn{2}{c}{ Varieties } \\
\cline { 2 - 5 } & Sugar Baby & Q-F-12 & D-W-H-21 & Red Circle-1885 \\
\hline Conjugated diene $\varepsilon^{1 \%}{ }_{1 \mathrm{~cm}}\left(\lambda_{232}\right)$ & $3.66 \pm 0.02^{\mathrm{bc}}$ & $3.94 \pm 0.11^{\mathrm{c}}$ & $4.40 \pm 0.25^{\mathrm{d}}$ & $2.90 \pm 0.11^{\mathrm{a}}$ \\
Conjugated triene $\varepsilon^{1 \%}{ }_{1 \mathrm{~cm}}\left(\lambda_{270}\right)$ & $3.09 \pm 0.15^{\mathrm{c}}$ & $2.15 \pm 0.13^{\mathrm{ab}}$ & $2.75 \pm 0.12^{\mathrm{bc}}$ & $2.05 \pm 0.09^{\mathrm{a}}$ \\
Peroxide value $\left(\mathrm{meqO}_{2} \mathrm{~kg}^{-1}\right.$ of oil) & $2.90 \pm 0.19^{\mathrm{a}}$ & $5.06 \pm 0.25^{\mathrm{d}}$ & $3.3 \pm 0.13^{\mathrm{b}}$ & $4.62 \pm 0.08^{\mathrm{c}}$ \\
$P$-anisidine value & $5.60 \pm 0.09^{\mathrm{a}}$ & $6.23 \pm 0.11^{\mathrm{ab}}$ & $7.70 \pm 0.15^{\mathrm{d}}$ & $6.35 \pm 0.12^{\mathrm{c}}$ \\
\hline
\end{tabular}

Different superscript letters within the same row indicate significant differences $(p<0.05)$ among varieties tested

Values are mean \pm SD of triplicate determinations 
(10.85 meqO $\mathrm{kg}^{-1}$ ) (Ardabili et al., 2011), varied significantly $(P<0.05)$ among the varieties selected.

The $p$-anisidine values of watermelon seed oils, within the range of 6.35 to 7.70 , indicated a reasonable resistance to secondary oxidation of these oils. Rancid and off-flavors are generally produced due to the presence of aldehydes of short or medium chain length. The present PV and $p$-anisidine values of Pakistani watermelon oils were found to be within the range of those reported (1.10$10.90 \mathrm{meqO}_{2} \mathrm{~kg}^{-1}$ and $0.20-9.00$, respectively) earlier for five varieties of melon seed oils investigated from Ghana by Mabaleha et al., (2007).

\subsection{Tocopherols of seeds oils}

The data for the quantification of tocopherols ( $\alpha$ and $\delta$ ) of the seed oils of the four varieties of watermelon is presented in Table 4. The total amounts, ranging from 140.6 to $222.6 \mathrm{mg} / \mathrm{kg}$, of these two tocopherol isomers varied significantly ( $p$ $<0.05)$ among the varieties tested. The contents $\left(\mathrm{mg} \mathrm{kg}^{-1}\right)$ of $\alpha$-tocopherol varied significantly $(P<$ 0.05 ) from $120.62-195.60 \mathrm{mg} / \mathrm{kg}$ with the highest level for the cultivar Sugar Baby and lowest in $\mathrm{D}-\mathrm{W}-\mathrm{H}-21$. Data are rarely available on the tocopherol contents of melon seed oil, yet the present $\alpha$-tocopherol levels are considerably higher than those found (27.10- $75.10 \mathrm{mg} \mathrm{kg}^{-1}$ ) in other Cucurbita maxima melon seed oil (Stevenson et al., 2007). On the other hand, the present $\delta$-tocopherol content, ranging from 9.08 to $58.29 \mathrm{mg} \mathrm{kg}^{-1}$, was found to be lower than that reported (74.90-492.80 $\mathrm{mg} / \mathrm{kg}$ ) for Cucurbita maxima seed oil (Stevenson et al., 2007). Gamma-tocopherol ( $\gamma$-tocopherol) and $\beta$-tocopherol were not detected in the present analysis of watermelon oils.

A considerable amount of $\alpha$-tocopherol (120.62$195.60 \mathrm{mg} \mathrm{kg}$ ) was detected in the present analysis of watermelon oils was found to be higher than those reported for palm oil (4-185 $\mathrm{mg} \mathrm{kg}^{-1}$ ) and coconut oil (not detected/ND-17 mg kg ${ }^{-1}$ ), while it was within the limits for soybean (9-352 $\mathrm{mg} \mathrm{kg}^{-1}$ ), maize (23-573 $\mathrm{mg} \mathrm{kg}^{-1}$ ), ground nut (49-304 mg $\mathrm{kg}^{-1}$ ) and high and low-erucic acid rapeseed (39$320 \mathrm{mg} \mathrm{kg}^{-1}$ ) oils (Rossell,1991). The $\delta$-tocopherol contents (9.08 and $58.29 \mathrm{mg} \mathrm{kg}^{-1}$ ), which were in close agreement with that of maize $\left(23-75 \mathrm{mg} \mathrm{kg}^{-1}\right)$, and lower than soybean (154-932 $\mathrm{mg} \mathrm{kg}^{-1}$ ), were established to be higher than those of coconut (ND-
$2 \mathrm{mg} \mathrm{kg}^{-1}$ ), cottonseed (ND-17 mg kg${ }^{-1}$ ), ground nut (3-22 $\mathrm{mg} \mathrm{kg}^{-1}$ ), palm (traces), sunflower (ND-7 mg $\left.\mathrm{kg}^{-1}\right)$, low, and high-erucic acid rapeseed (4-22 mg $\mathrm{kg}^{-1}$ ) oils (Rossell,1991).

Tocopherols are minor components that contribute significantly to the oxidative stability of vegetable oils during storage and processing. They are naturally present in vegetable oilseeds and extracted along with the oils, however, their concentration usually decreases as result of oil processing. In vegetable oils, their original concentration may vary from a few $\mathrm{mg} / \mathrm{kg}$ to a thousand $\mathrm{mg} \mathrm{kg}^{-1}$ or even more depending on the oil type and oil fatty acid composition (Rossell, 1991). Of the different isomers of tocopherols reported so far, $\alpha$ isomer has the greatest vitamin E efficacy, while $\delta$-exhibits the highest antioxidant activity (Timmermann, 1990; Sies and Murphy, 1991; Matthaus and Ozcan, 2009).

\subsection{Fatty acid composition}

The data related to fatty acid composition for the seed oils of different varieties of watermelon as analyzed by GLC-FID are shown in Table 5 . The contents of palmitic acid and stearic acid varied from $14.3-16.2 \%$ and $11.2-13.8 \%$, respectively. The total amounts of these two saturated fatty acids (TSFA) were the highest in the watermelon var. D-W-H-21 $(30.0 \%)$ while the lowest were found in var. Sugar Baby (26.2\%). The present TSFA levels were found to be higher than those reported (17.8\%) earlier in Citrullus lanatus var. Colocynthoide (Ziyada and Elhaussien, 2007). These TSFA varied slightly from those (12.0-36.0\%) investigated for different species of musk melon seed oils (Tilak et al., 2006).

The watermelon seed oils tested contained relatively higher levels (68.1-72.3\%) of unsaturated fatty acids with linoleic acid (45.1-51.2\%) as the major component. The oils also contained appreciable amounts of oleic acid with contributions of 20.2 to $23.0 \%$. The contents of total unsaturated fatty acids (TUFA), comprising linoleic and oleic acids, was found to be the highest $(72.3 \%)$ in the watermelon var. Sugar Baby while the lowest $(68.1 \%)$ was found for D-W-H-21. The contents of TUFA in the present analysis were found to be lower than those reported by Baboli and Kordi (2010) (81.6\%). However, these levels of TUFA were in line with those detected (67.93-82.36\%) in five species of melon by Mabaleha et al., (2007).

Table 4

Tocopherol contents of different varieties of watermelon seed oils

\begin{tabular}{lcccc}
\hline \multirow{2}{*}{ Tocopherol $\left(\mathbf{m g ~ k g}^{-1}\right)$} & \multicolumn{4}{c}{ Varieties } \\
\cline { 2 - 5 } & Sugar Baby & Q-F-12 & D-W-H-21 & Red Circle-1885 \\
\hline$\alpha$-tocopherol & $195.6 \pm 12.20^{\mathrm{d}}$ & $164.3 \pm 5.60^{\mathrm{c}}$ & $122.0 \pm 7.10^{\mathrm{ab}}$ & $120.6 \pm 10.25^{\mathrm{a}}$ \\
$\delta$-tocopherol & $12.3 \pm 0.90^{\mathrm{a}}$ & $58.3 \pm 1.20^{\mathrm{d}}$ & $9.1 \pm 0.50^{\mathrm{a}}$ & $20.0 \pm 1.10^{\mathrm{b}}$ \\
Total tocopherol & $207.9^{\mathrm{c}}$ & $222.6^{\mathrm{cd}}$ & $131.1^{\mathrm{a}}$ & $140.6^{\mathrm{ab}}$ \\
\hline
\end{tabular}

Different superscript letters within the same row indicate significant differences $(p<0.05)$ among varieties tested

Values are mean \pm SD of triplicate determinations 
Table 5

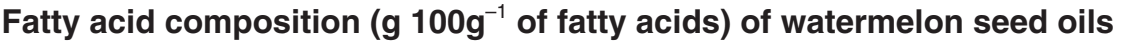

\begin{tabular}{lcccc}
\hline \multirow{2}{*}{ Fatty acids } & \multicolumn{4}{c}{ Varieties } \\
\cline { 2 - 5 } & Sugar Baby & Q-F-12 & D-W-H-21 & Red Circle 1885 \\
\hline $\mathrm{C}_{16: 0}$ & $15.0 \pm 0.05^{\mathrm{a}}$ & $15.1 \pm 0.12^{\mathrm{ab}}$ & $16.2 \pm 0.08^{\mathrm{b}}$ & $14.3 \pm 0.99^{\mathrm{a}}$ \\
$\mathrm{C}_{18: 0}$ & $11.2 \pm 0.52^{\mathrm{a}}$ & $12.5 \pm 0.06^{\mathrm{bc}}$ & $13.8 \pm 0.06^{\mathrm{cd}}$ & $12.3 \pm 0.62^{\mathrm{c}}$ \\
$\mathrm{C}_{18: 1}$ & $21.2 \pm 0.45^{\mathrm{b}}$ & $20.2 \pm 0.95^{\mathrm{a}}$ & $23.0 \pm 0.09^{\mathrm{c}}$ & $20.2 \pm 0.65^{\mathrm{ab}}$ \\
$\mathrm{C}_{18: 2}$ & $51.1 \pm 0.09^{\mathrm{d}}$ & $50.5 \pm 0.09^{\mathrm{d}}$ & $45.1 \pm 0.80^{\mathrm{a}}$ & $51.2 \pm 0.05^{\mathrm{d}}$ \\
Unidentified $^{\mathrm{d}}$ & 1.5 & 1.7 & 1.9 & 2.0 \\
$\quad$ TSFA & 26.2 & 27.6 & 30.0 & 26.6 \\
TUFA & 72.3 & 70.7 & 68.1 & 71.4 \\
TEFA & 51.1 & 50.5 & 45.1 & 51.2 \\
\hline
\end{tabular}

Different letters in superscript within the same row indicate significant differences $(p<0.05)$ among the varieties tested

Values are mean \pm SD of triplicate determinations

TSFA: Total saturated fatty acids

TUSF: Total unsaturated fatty acids

TEFA: Total essential fatty acid

The amount of TUSFA in the present analysis are comparable with those reported (64.6-88.2\%) for different species of muskmelon (Tilak et al., 2006).

The contents of linoleic acid, an essential fatty acid (EFA), were $45.1-51.2 \%$. EFA have potential health benefits related to cardiovascular disorders (Nicolosi et al., 2004, Manzoor et al., 2007). The fatty acid profile of watermelon seeds oil shows relatively low amounts (26.2-30.0\%) of TSFA and high amounts of EFA, which is advantageous due to the fact that a diet low in saturates can benefit patients with cardiovascular diseases (Nicolosi et al., 2004).

\section{CONCLUSION}

The results of the present study demonstrated that the seeds from the watermelon varieties tested are a good source of high-linoleic oil that might be utilized for human consumption as well as for other oleochemical purposes. In addition, it was evident from the present findings that the oil yield and most of the other physicochemical attributes of the oils extracted considerably varied among the varieties of watermelon tested.

\section{REFERENCE}

Achu BM, Fokou E, Tchiegang C, Fosto M, Tchouanguep FM. 2005. Nutritive value of some Cucurbitaceae oilseeds from different regions in Cameroon. Afr. J. Biotechnol. 4, 1329-1334.

Adhikari P, Hwang KT, Shin MK, Lee BK, Kim SK, Kim SY, Lee KT, Kim SZ. 2008. Tocols in craneberry seed oils. Food Chem. 111, 687-690.

Amercian Oil Chemist's Socity (AOCS), 1997. Official and Recommended Practices of the AOCS, $7^{\text {th }}$ edition, AOCS Press, Champaign.

Anhwange BA, Ajibola VO, Oniye SJ. 2004. Chemical studies of the seeds of Moringa oleifera (Lam) and
Detarium microcarpum (Guill and Sperr). J. Biol. Sci. 4(6), 711-715.

Anwar F, Latif S, Ashraf M. 2006. Analytical characterization of hemp (Cannabis sativa) seed oil from different agro-ecological zones of Pakistan. J. Am. Oil Chem. Soc. 83, 323-329.

Anwar F, Naseer R, Bhanger MI, Ashraf S, Talpur FN, Aladedunye FA. 2008. Physiochemical characterization of citrus seeds and seed oil from Pakistan. J. Am. Oil Chem. Soc. 85, 321-330.

Anwer T, Banger MI, Anwar F, Khan M, Shahid R, lqbal S. 2006. A comparative characterization of different non-conventional oilseeds found in Pakistan. J. Chem. Soc. Pak. 28, 144-148.

Ardabili GA, Farhoosh R, Khodaparast HHM. 2011. Chemical composition and physicochemical properties of Pumpkin Seeds (Cucurbita pepo Subsp. Pepo Var. Styriaka) Grown in Iran. J. Agr. Sci. Tech. 13, 1053-1063.

Artwatermelon. 2007. http://www.foodreference.com. (Accessed on Web12.09.2007).

Association of Official Analytical Chemists (AOAC), 1990. Determination of total protein contents, standard method 976.06

Baboli ZM, Kordi AAS. 2010. Characteristics and Composition of Watermelon Seed Oil and Solvent Extraction Parameters Effects. J. Am. Oil Chem. Soc. 87, 667-671.

Bockisch M.1993. Handbuch der Lebensmitteltechnologie. Ulmer, Stuttgart: Nahrungsfette und Oele.

Celik F, and Ercisli S. 2009. Lipid and fatty acid composition of wild and cultivated red raspberry fruits (Rubus idaeus L.). J. Med. Plants Res. 3, 583-585.

El-Adawy TA, Taha KM. 2001. Characteristics and composition of Watermelon, Pumpkin, and Paprika seed oils and flours. J. Agric. Food Chem. 49, 1253-1259.

Frankel, EN. 2005. Lipid oxidation. The Oily Press, Bridgwater, England.

Gordon MH, Magos P. 1983. The effect of sterols on the oxidation of edible oils. . Food Chem. 10, 141.

International Organization for Standardization (ISO) 1977. Oilseed residues determination for total ash ISO, Geneva Standard No. 749.

International Organization for Standardization (ISO) 1981. Animal Feeding Stuffs- Determination of 
Nitrogen and Calculation of Crude Protein content, ISO Geneva, Standard No.5983.

International Union of Pure and Applied Chemistry (IUPAC), 1987. Standard Methods for the Analysis of Oils, Fats and Derivatives, $7^{\text {th }}$ rev. enlarged edn., edited by C. Paquot and A. Hautfenne, Blackwell Scientific, London.

Mabaleha MB, Mitei YC, Yeboah SO. 2007. A comparative study of the properties of selected melon seed oils as potential candidates for development into commercial edible vegetable oils. J. Am. Oil Chem. Soc. 84, 31-36.

Malecka M. 1994. The effect of squalene on the thermostability of rapeseed oil. Nahrung, $\mathbf{3 8}, 135$.

Manzoor M, Anwar F, Iqbal T, Bhanger MI. 2007. Physicochemical characterization of Moringa concanensis seed and seed oil. J. Am. Oil Chem. Soc. 84, 413-419.

Matthaus B, and Ozcan MM. 2009. Fatty acids and tocopherol contents of some Prunus spp. Kernel oil. J. Food Lipids. 16, 187-199.

Nehdi IA. 2011. Characteristics and composition of Washingtonia filifera (Linden ex André) $\mathrm{H}$. Wendl. seed and seed oil. Food Chem. 126, 197-202.

Nicolosi RJ, Woolfrey B, Wilson TA, Scollin P. Handelman G, Fisher R. 2004. Decreased aortic early atherosclerosis and associated risk factors in hypercholesterolemic hamsters fed a high- or midoleic acid oil compared to a high-linoleic acid oil. J. Nut. Biochem. 15, 540-547.

Oyedeji FO, Oderinde RA. 2006. Characterization of isopropanol extracted vegetable oil. J. App. Sci. 6, 2510-2513.

Pakistan Oilseeds and Products Annual (POPA) Report. 2011. Written by Shafiq-Ur-Rehman approved by Joseph MC. Report Number: PK11003.

Parry J, Su L, Luther M, Zhou K, Yurawecz MP, Whittaker $\mathrm{P}$, and Yu L. 2005. Fatty acid composition and antioxidant properties of cold-pressed marionberry, boysenberry, red raspberry, and blueberry seed oils. J. Agric. Food Chem. 53, 566-573.

Pritchard JLR (1991). Analysis and properties of oilseeds. In: Rossell JB, Pritchard JLR (eds) Analysis of oilseeds, fats and fatty foods. Elsevier Applied Sciences, New York, pp 39-102.
Ramadan MF, Sharanabasappa G, Parmjyothi S, Seshagiri M, and Moersel JT. 2006. Profile and levels of fatty acids and bioactive constituents in mahua butter from fruit-seeds of buttercup tree [Madhuca longifolia (Koenig)]. Eur. Food Res. Technol. 222, 710-718.

Rossell, JB.1991. Vegetable oil and fats. In Analysis of Oilseeds, Fats and Fatty Foods; Rossell, J. B., and Pritchard, J. L. R. Eds; Elsevier Applied Science: New York., pp 261-328.

Sies H, and Murphy ME. 1991. Role of tocopherols in the protection of biological systems against oxidative damage. J. Photochem. Photobiol. B: Biol. 8, 211224.

Steel RGD, Torrie JH, Dickey D. 1997. Principles and procedures of statistics. A biometrical approach, $3^{\text {rd }}$ edition. McGraw Hills, New York, USA.

Stvenson DG, Eller FJ, Wang L, Jane JL, Wang T, Inglett GE. 2007. Oil and tocopherol content of composition of pumpkin seeds oil in 12cultivars. J. Agri. Food Chem. 55, 4005-4013.

Taiwo AA, Agbotoba MO, Oyedepo JA, Shobo OA, Oluwadare I, Olawunmi MO. 2008. Effects of drying methods on properties of water melon (Citrullus lanatus) seed oil. Afr. J. Food Agr. Nutr. Dev. 8, 16845374.

Tilak RM, Tukaram A, Brij ML, Valangaman SS. 2006. A study of seeds of musk melon (Cucumis melo L.), A lesser known source of edible oil. J. Sci. Food Agri. 10, 973-978.

Timmermann F. 1990. Tocopherole - Antioxidative wirkung bei fetten und ölen. Fat Sci. Technol. 92, 201-206.

Wrolstad, R.E. 2003. Analysis of Tocopherols and Tocotrienols. In: Current Protocols in Food Analytical Chemistry (CPFA), (Eds.): R. E. Wrolstad, John Wiley \& Sons.

Ziyada AK, Elhussien SA. 2008. Physical and chemical characteristics of Citrullus lanatus Var. Colocynthoide seed oil. J. Phy. Sci. 19, 69-75. 